\title{
MINERAL CONTENT IN RELATION TO RADIAL POSITION, ALTITUDE, CHEMICAL PROPERTIES AND DENSITY OF PERSIAN IRONWOOD
}

\author{
Majid Kiaei ${ }^{1, \wedge}$, Behzad Kord ${ }^{2}$, Ahmad Chehalmardian ${ }^{3}$, Roger Moya ${ }^{4}$, Mohammad Farsi ${ }^{1}$
}

\begin{abstract}
Persian ironwood (Parrotia persica) is native species from Iran and covers $10,54 \%$ of the commercial volume. Its wood structure and its chemical composition are affected by growth conditions. The aim of the study was to assess the variation of mineral content $(\mathrm{Ni}, \mathrm{Fe}, \mathrm{Cu}, \mathrm{Zn}, \mathrm{Pb}, \mathrm{Cd})$, wood density and chemical properties (cellulose, lignin, ash and extractive) of ironwood in relation to altitude above sea level (100, 500 and 700 meter) and pith distance within stem (near to pith and bark and middle point). In addition was investigate the relationship between mineral content with oven-dried density and chemical properties. Results showed that $\mathrm{Cd}, \mathrm{Cu}, \mathrm{Fe}, \mathrm{Ni}$ and $\mathrm{Zn}$ content (except $\mathrm{Pb}$ concentration) increased by increasing of altitude and decreased along radial position within stem from the pith to the bark. Lignin, ash and extractive content increased by increasing altitudes from 100 to 700 meter while cellulose decreased. Radial position had not significant impact on the chemical properties. There are significant relationships between mineral content-chemical properties and between mineral content-wood density (except $\mathrm{Cu}$ - density). Forward stepwise regression showed that ash and lignin content had important role on the variation of all of mineral content except on $\mathrm{Cd}$.
\end{abstract}

Keywords: Ash content, cellulose, chemical properties, density, lignin, Parrotia persica, wood variation.

\section{INTRODUCTION}

Persian ironwood (Parrotia persica) is one of the deciduous trees of Hyrcanian forests (Northern coast of the Caspian Sea in Iran) are from the Hamamelidaceae family (Parsakhoo and Jalilvand 2009). Parrotia persica is usually a low-branched and multi stemmed small specimen tree. Persian Parrotia provides significant autumn and winter interest (Parsakhoo and Jalilvand 2009).

This species, as many others, is affected by genotype and ecological conditions of the trees habitat which have impact on the growth and development of the trees (Yilmaz et al. 2008). Ecologic conditions of site directly or indirectly affect the availability, development and fertility, body form and height of tree types, herbal type variety, stand closure and availability rates of plants (Creber and Chaloner 1984, Tessier et al. 1994, RooZielinska and Solon 1997, Yilmaz et al. 2008, Wodzicki 2001), and they resemble different wood properties.

\footnotetext{
Department of Wood and Paper Science and Technology, Sari Branch, Islamic Azad University, Sari, Mazandaran, Iran.

2 Department of Paper and Packaging Technology, Faculty of Chemistry and Petrochemical Engineering, Standard Research Institute (SRI), Karaj, Iran.

${ }^{3}$ Department of Wood and Paper Science and Technology, Chaloos Branch, Islamic Azad University, Chaloos, Mazandaran, Iran.

${ }^{4}$ Escuela de Ingeniería Forestal, Instituto Tecnológico de Costa Rica, Cartago, Costa Rica.

^ Corresponding author: mjd_kia59@yahoo.com

Received: 11.09.2014 Accepted: 20.03.2015
} 
The factors that cause the changes in the wood structure are the age and genetic properties of the tree and the environmental conditions (Doğu 2002). These factors affect the growth rate of tree, composition, structure and wood different properties (Wilson and White 1986). Wood density (important wood properties) is a complex physical property, related to the anatomical structure, including cell wall thickness, vessel number and characteristics, and the wood chemical composition, including extractives contents, that responds to genetic, environmental and physiological influences (Wimmer et al. 2002, Wimmer et al. 2008, Trugilho et al. 1996, Zhang and Morgenstern 1995, Hylen 1997, Zhang 1998). Site and environmental conditions affect density of wood and therefore its properties (Moya and Perez 2008, Silva et al. 2009, Moya and Calvo-Alvarado 2012, Zobel and Van Buijtenen 1989).

Important wood properties, as ash content from hardwood species produces higher levels of macronutrients in their ash than conifers, and the silica content is frequently lower (Pitman 2006). Ash derived from branch and root wood is richer in many elements than stemwood, while that derived from bark and foliage has concentrations between five and 10 times greater than from stemwood (Werkelin et al. 2005). Bark thus produces more ash than stemwood (Pitman 2006).

Mineral nutrients are limiting resources to plants and the allocation and translocation of mineral nutrients among different organs are important mechanisms enhancing nutrient use efficiency in plants (Aerts and Chapin 2000, Eckstein 1999, Nambiar and Fife 1991, Meerts 2002). In trees, wood usually has the lowest mineral nutrient concentration of all organs (Woodwell et al. 1975). However, wood itself is not necessarily homogeneous with respect to mineral element concentrations (Hillis 1987, Myre et al. 1994). There is a higher of P, N and K concentration in sapwood compared to heartwood for oakwood (Attiwill 1980, Augusto et al. 2000, Penninckx et al. 2001).

Although, there is much information about the mineral content in relation to pith distance and other important aspect to relation with growing condition, information about variation of the mineral content in Parrotia persica is less known. Therefore, the objectives of this research were: a) to examine the effect of altitude and radial position on different wood properties such as chemical properties, wood density and mineral content on Parrotia persicain Noshahr region located in Iranian forest, and b) to investigate the relationship between chemical properties and wood density with mineral content by Pearson correlation and forward stepwise regression.

\section{METHODS}

\section{Experimental material}

In the present study, 9 normal Persian ironwood (Parrotia persica (DC) CA Meyer) trees were felled from three different altitudes, i. e., 100 (low elevation), 500 (intermediate elevation), and 700 (high elevation) meters above sea level from northern natural forests (Noshahr region) in Iran. At all three sites, the trees were 35-40 years-old. All nine trees were randomly selected, taking into account stem straightness and the absence of evident decay. Traits of environmental and climate conditions of these sites and characteristics of trees are listed in Table 1. A cross-section with $15 \mathrm{~cm}$ in thickness was extracted from each tree at breast height. This cross-section was utilized for evaluation of wood properties. Afterwards, three samples were prepared along radial position from pith to the bark (near to pith, middle between pith and bark, near to the bark). Wood density (according to ISO-3131) and chemical properties (according to TAPPI standard) were determined in each position. 
Table 1. The characteristics of the sites, and climate of Persian Ironwood (Parrotia persica) plantation studied in Iran.

\begin{tabular}{|ccllllll|}
\hline Sites & $\begin{array}{c}\text { Altitudes } \\
(\mathrm{m})\end{array}$ & Soil type & $\begin{array}{c}\text { Annual } \\
\text { temperature } \\
\left({ }^{\circ} \mathrm{C}\right)\end{array}$ & $\begin{array}{c}\text { Annual } \\
\text { rainfall }(\mathrm{mm})\end{array}$ & Height $(\mathrm{m})$ & $\begin{array}{c}\text { Diameter } \\
(\mathrm{cm})\end{array}$ \\
\hline \multirow{3}{*}{ Noshahrregion } & 100 & Alfisols & 13,5 & 1,345 & 23,4 & 32 \\
& 500 & Alfisols & 11,5 & 1,300 & 23,3 & 31,6 \\
& 700 & Alfisols & 8,5 & 1,300 & 22,5 & 30,4 \\
\hline
\end{tabular}

\section{Chemical properties and mineral content}

All of radial samples were milled to wood flour to examine chemical properties and mineral content. Lignin, ash and extractives soluble in alcohol-acetone were determined according to TAPPI test methods. The cellulose content of iron wood was determined according to the nitric acid method (Rowell et al. 1997). Then the mineral content such as Nickel (Ni), iron (Fe), copper $(\mathrm{Cu})$, Zinc $(\mathrm{Zn})$, plumb $(\mathrm{Pb})$, and Cadmium (Cd) dissolved and separated from ash of wood flour by $63 \%$ nitric acid for an hour, mineral content of iron wood identifications by atomic adsorption system (Varian AA240, Australia). All of measurements (mineral content and chemical properties) were repeated three times.

\section{Wood density measurement:}

First, the specimens ( 3 Tree $\mathrm{x} 4$ geographical directions (north, south, east, west) $\mathrm{x} 3$ position $\mathrm{x} 3$ altitude classes $=108$ samples) were soaked in distilled water for $72 \mathrm{~h}$ in order to ensure that the moisture content could reach the fiber saturation point. Then the dimensions in all three radial positions were measured with a digital caliper $( \pm 0,001 \mathrm{~mm})$. Specimens were also weighed to the nearest $0,001 \mathrm{~g}$. Finally, the samples were oven dried at $103 \pm 2{ }^{\circ} \mathrm{C}$ to $0 \%$ moisture content. After cooling in desiccators, the oven-dry weights of the specimens were measured. The oven-dry density of the specimens was calculated by the following equations:

$$
D_{0}(\text { density })=\frac{p_{0}(\text { oven }- \text { dried } \text { weight })}{v_{0}(\text { oven }- \text { dried volume }}
$$

\section{Statistical analysis}

First, the assumptions of normal distribution, variance homogeneity and absence of extreme data of different mineral content ( $\mathrm{Ni}, \mathrm{Pb}, \mathrm{Cd}, \mathrm{Cu}, \mathrm{Zn}$ and $\mathrm{Fe}$ ) were verified. ProcUnivariate procedure was applied of SAS 8.1 for Windows (SAS Institute Inc., Cary, N.C.). Second, the values of each mineral relation to radial position and altitude were compared by ANOVA procedure from SAS (SAS Institute, 1997). The following statistical model was used:

$$
Y_{i j k}=\mu+p_{i}+a_{j}+p^{*} a_{i j}+e_{i j k}
$$

where $Y_{i j k}$ is the single observation of each mineral of the $\mathrm{ij}$ th-tree, $\mu$ is the overall mean, $p$ is the $i^{\text {th }}$-radial position fixed effect, $a$ is $\mathrm{j}^{\text {th }}$-altitude fixed effect, $p^{*} a_{i j}$ is the random interaction between the $i^{\text {th }}$ radial position and the $j^{\text {th }}$ altitude and $e_{i j k}$ is the residual random effect. 
The average differences were analyzed by Duncan test with 0,01 in significance in order to find which treatments varied. And third, a Pearson correlation matrix was used for determining the relationships of different mineral content with some wood properties (density oven-dried, and chemical composition, specifically ash, cellulose and lignin content and extractives in alcohol-acetone. Four, forward stepwise analysis was carried out for defining the priority wood properties affecting the mineral content the most. Finally, three-dimensional graphs (XYZ) were performed as graphical support to relation between mineral content and two main variables with most effects indicated forward stepwise analysis.

\section{RESULTS}

\section{Effects of radial position and altitude on chemical properties}

The average and standard deviation of chemical properties in relation to radial position for iron wood growing in three different elevations were shown in table 2. Analysis of variance results (ANOVA) indicated that the effect of altitude on the chemical properties was significant, while radial position and their interaction hadn't significant differences on the chemical properties of ironwood (Table 3). The mean of lignin, extractive and ash were increased by increasing of altitude in ironwood. The cellulose content is higher at low altitude $(44,70 \%)$ and lower at high altitude $(43,53 \%$ in altitude $500 \mathrm{~m}$ and $43,68 \%$ in altitude $700 \mathrm{~m})$ in this region (Table 2). Regular pattern of chemical properties variations (except ash content) weren't observed along radial position from the pith to the bark at three studied altitudes. There is an insignificantly decreasing trend of ash variation along radial position from pith to bark in each of fixed elevation (Table 3). The standard deviation of chemical variation except lignin content in high altitude is higher than other altitudes (Table 2).

Table 2. Chemical properties in relation to radial position for Persian ironwood (Parrotia persica) growing in three different altitude of Iran.

\begin{tabular}{|llcccc|}
\hline $\begin{array}{l}\text { Altitude } \\
(\mathrm{m})\end{array}$ & Radial position & $\begin{array}{c}\text { Cellulose } \\
(\%)\end{array}$ & $\begin{array}{c}\text { Lignin } \\
(\%)\end{array}$ & $\begin{array}{c}\text { Extractives } \\
(\%)\end{array}$ & $\begin{array}{c}\text { Ash } \\
(\%)\end{array}$ \\
\hline \multirow{3}{*}{100} & Pith & $44,79(0,50)$ & $23,65(0,25)$ & $2,60(0,16)$ & $1,15(0,15)$ \\
& Middle & $44,80(0,37)$ & $23,82(0,17)$ & $2,62(0,20)$ & $0,93(0,13)$ \\
& Bark & $44,50(0,33)$ & $23,71(0,36)$ & $2,59(0,31)$ & $0,74(0,25)$ \\
& Average & $44,70(0,38)$ & $23,73(025)$ & $2,60(0,20)$ & $0,94(0,24)$ \\
\hline \multirow{3}{*}{500} & Pith & $43,49(0,63)$ & $25,11(0,63)$ & $4,08(0,25)$ & $1,78(0,13)$ \\
& Middle & $43,60(0,62)$ & $25,01(0,52)$ & $3,62(0,43)$ & $1,69(0,14)$ \\
& Bark & $43,51(0,32)$ & $24,62(0,45)$ & $3,92(0,27)$ & $1,66(0,23)$ \\
& Average & $43,53(0,47)$ & $24,91(0,52)$ & $3,87(0,35)$ & $1,71(0,16)$ \\
\hline \multirow{3}{*}{700} & Pith & $42,15(0,66)$ & $26,11(0,23)$ & $4,77(0,32)$ & $2,20(0,36)$ \\
& Middle & $43,81(0,88)$ & $25,50(0,56)$ & $4,62(0,31)$ & $2,05(0,28)$ \\
& Bark & $43,77(0,65)$ & $25,86(0,32)$ & $4,04(0,39)$ & $1,95(0,24)$ \\
& Average & $43,68(0,94)$ & $25,83(0,43)$ & $4,48(0,44)$ & $2,07(0,28)$ \\
\hline \multirow{3}{*}{ Total } & Pith & $43,48(1,26)$ & $24,96(1,13)$ & $3,82(0,98)$ & $1,71(0,50)$ \\
& Middle & $43,81(0,88)$ & $24,78(0,84)$ & $3,62(0,91)$ & $1,56(0,52)$ \\
& bark & $43,77(0,65)$ & $24,73(0,99)$ & $3,52(0,75)$ & $1,45(0,58)$ \\
& Average & $43,68(0,94)$ & $24,82(0,96)$ & $3,65(0,86)$ & $1,57(0,53)$ \\
\hline
\end{tabular}

Legend: Standards errors are presented in brackets. 
Table 3. Results from ANOVA: F-value (in analysis of variance) of the results of chemical properties in Persian ironwood (Parrotia persica) trees growing in Iran.

\begin{tabular}{|c|c|c|c|c|}
\hline Chemical properties & Cellulose (\%) & Lignin (\%) & Extractives (\%) & Ash (\%) \\
\hline Altitude (A) & $31,10^{* *}$ & $56,10^{* *}$ & $85,67^{* *}$ & $56,98^{* *}$ \\
\hline Radial position (B) & $1,16^{\mathrm{ns}}$ & $0,720^{\mathrm{ns}}$ & $2,185^{\mathrm{ns}}$ & $2,96^{\mathrm{ns}}$ \\
\hline A $\times$ B & $1,727^{\mathrm{ns}}$ & $1,058^{\mathrm{ns}}$ & $2,073^{\mathrm{ns}}$ & $0,31^{\mathrm{ns}}$ \\
\hline
\end{tabular}

Ns: not significant; $* *$ significant at 0,01 level.

\section{Effects of radial position and altitude on wood density}

The average and standard deviation of wood density in relation to radial position for iron wood growing in three different elevations were shown in table 4 . Analysis of variance results (ANOVA) indicated that the effect of altitude $(F=8,738 ; p=0,002)$, radial position $(F=14,493 ; p=0)$ and their interaction $(F=2,983 ; p=0,047)$ on the wood density were significant. The highest and lowest of wood density were found at intermediate $(0,796$ $\left.\mathrm{g} \mathrm{cm}^{-3}\right)$ and low altitudes $\left(0,733 \mathrm{~g} \mathrm{~cm}^{-3}\right)$, respectively. The variation of wood density along radial position from pith to the bark was decreased in each of fixed altitude (Table 4). The mean of wood density was 0,769 $\mathrm{g} \mathrm{cm}^{-3}$ for three studied altitudes in north of Iran.

Table 4. Wood density $\left(\mathrm{g} / \mathrm{cm}^{3}\right)$ in relation to radial position for Persian ironwood (Parrotia persica) growing in three different altitude of Iran

\begin{tabular}{|lllll|}
\hline Altitude/position & Pith & Middle & bark & Average \\
\hline 100 & $0,810(0,072)$ & $0,706(0,020)$ & $0,683(0,057)$ & $0,733(0,069)$ \\
500 & $0,806(0,020)$ & $0,796(0,025)$ & $0,786(0,025)$ & $0,796(0,022)$ \\
700 & $0,823(0,037)$ & $0,790(0,026)$ & $0,720(0,017)$ & $0,777(0,051)$ \\
Average & $0,813(0,042)$ & $0,764(0,048)$ & $0,730(0,047)$ & $0,769(0,056)$ \\
\hline
\end{tabular}

Legend: Standards errors are presented in brackets.

\section{Effects of radial position and altitude on mineral content}

Analysis of variance results (ANOVA) indicated that the radial position, altitude and their interaction (except for $\mathrm{Cd}$ and $\mathrm{Pb}$ ) had significant differences on mineral concentration in iron wood for this region (Table 5). Radial variations of mineral content of ironwood for three different altitudes and for interaction radial position $\mathrm{x}$ altitude were shown in figures 1 to 3 , respectively. The average of $\mathrm{Ni}(0,07-2,21 \mathrm{ppm}), \mathrm{Cd}$ $(0,05-0,29 \mathrm{ppm}), \mathrm{Cu}(0,17-1,18 \mathrm{ppm}), \mathrm{Zn}(1-2,43 \mathrm{ppm})$ and $\mathrm{Fe}(0,62-1,02 \mathrm{ppm})$ were increased by increasing of altitude (Figure 1a, 1c-f). In each of fixed altitude, the mentioned properties were decreased along radial position from the pith to the bark (Figure 2). $\mathrm{Pb}$ concentration $(0,13-0,91 \mathrm{ppm})$ is higher at low altitude and lower at high altitude (Figure 1b). Pattern variation of $\mathrm{Pb}$ concentration was increased along radial direction from pith to the bark in ironwood (Figure 2b).

Table 5. $F$-value (in analysis of variance) of the results of mineral content in Persian ironwood (Parrotia persica) trees growing in Iran.

\begin{tabular}{|lllllll|}
\hline Mineral content & $\mathrm{Ni}$ & $\mathrm{Pb}$ & $\mathrm{Cd}$ & $\mathrm{Cu}$ & $\mathrm{Zn}$ & $\mathrm{Fe}$ \\
\hline Altitude (A) & $1762,2^{* *}$ & $682^{* *}$ & $721,2^{* *}$ & $320,5^{* *}$ & $1255^{* *}$ & $534,1^{* *}$ \\
Radial position (B) & $304,96^{* *}$ & $76,95^{* *}$ & $46,76^{* *}$ & $48,92^{* *}$ & $72,51^{* *}$ & $72,91^{* *}$ \\
$(\mathrm{~A} \times \mathrm{B})$ & $1,03 * *$ & $1,09^{\mathrm{ns}}$ & $1,15^{\mathrm{ns}}$ & $5,08^{* *}$ & $7,42^{* *}$ & $3,71^{*}$ \\
\hline
\end{tabular}

and ${ }^{*}$ were significant at 0,01 and 0,05 ; ns: is not significant 

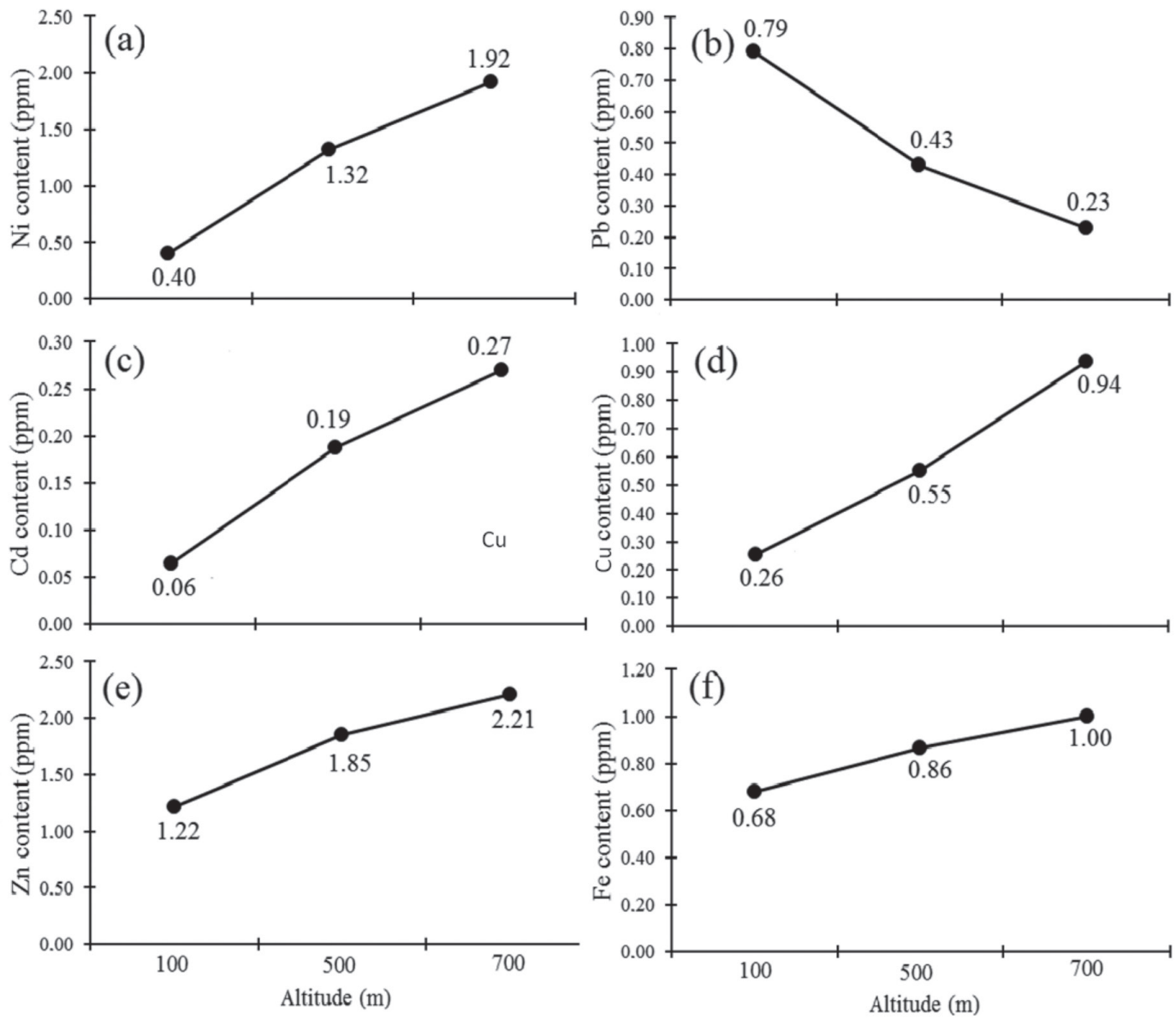

Figure 1. Nickel (a), plumb (b), cadmium (c), copper (d), zinc (e) and iron (f) content variation of Persian ironwood (Parrotia persica) growing in three different altitude of Iran. 

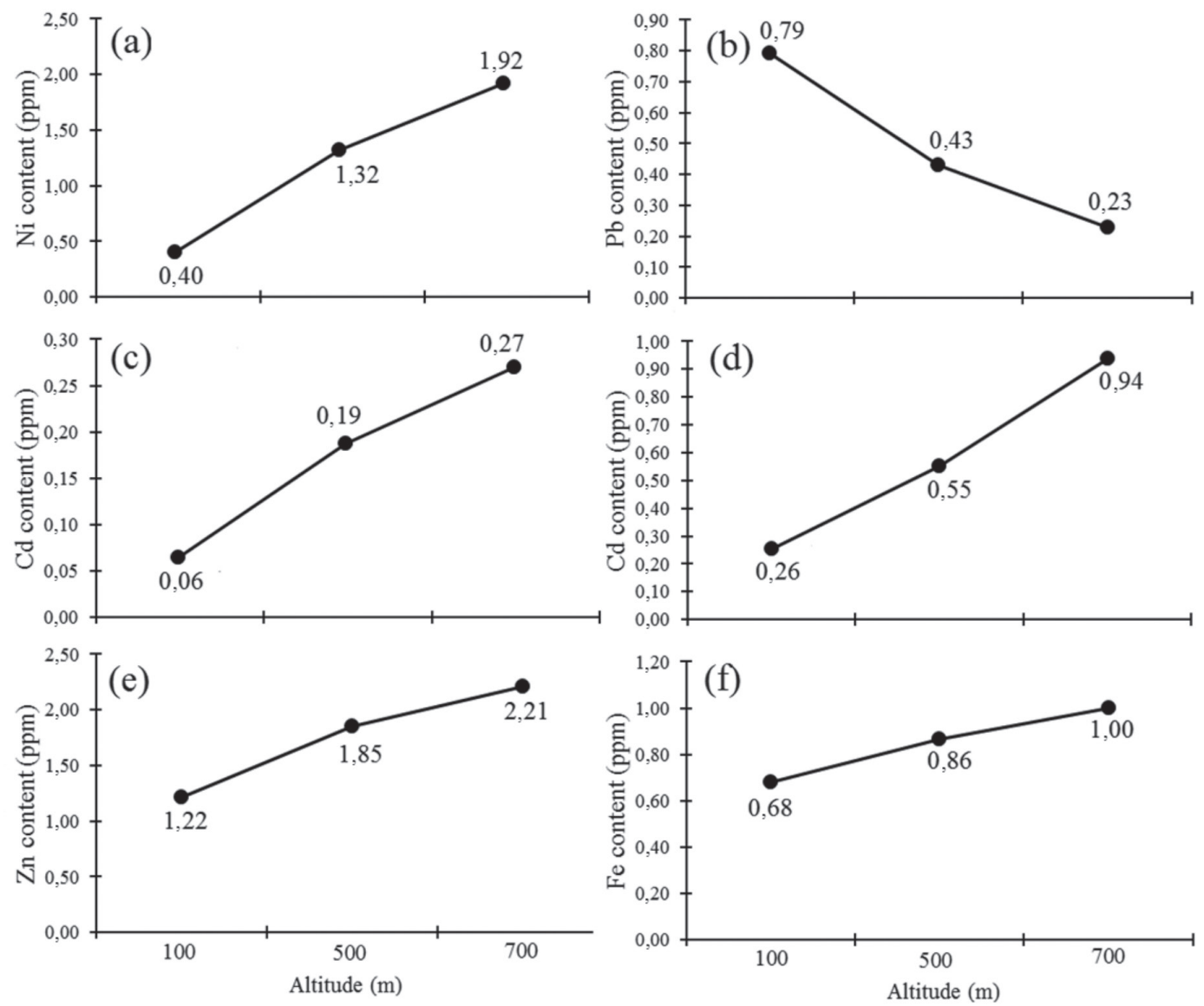

Figure 2. Nickel (a), plumb (b), cadmium (c), copper (d), zinc (e) and iron (f) content variation in relation to radial position for Persian ironwood (Parrotia persica)

growing in three different altitude of Iran.

Another important observation was that almost of values of mineral were statically different between them in trees growing in altitude of 100 and $700 \mathrm{~m}$ (Table 5), but trees growing in altitude of 500, some radial position were not statistically different. For example, $\mathrm{Cu}$ content in wood middle distance between pith-bark was not difference with wood near to bark in altitude $500 \mathrm{~m}$ (Figure 3D). Zn and Fe content were statistically equal in wood near pith and in middle distance (Figure 3E and 3F). Besides other radial position were similar in trees growing in different altitude, For example, $\mathrm{Cd}$ content in wood near pith in trees growing at altitude of 500 was not difference with wood near to bark in trees growing at $700 \mathrm{~m}$ in altitude (Figure 3C). 

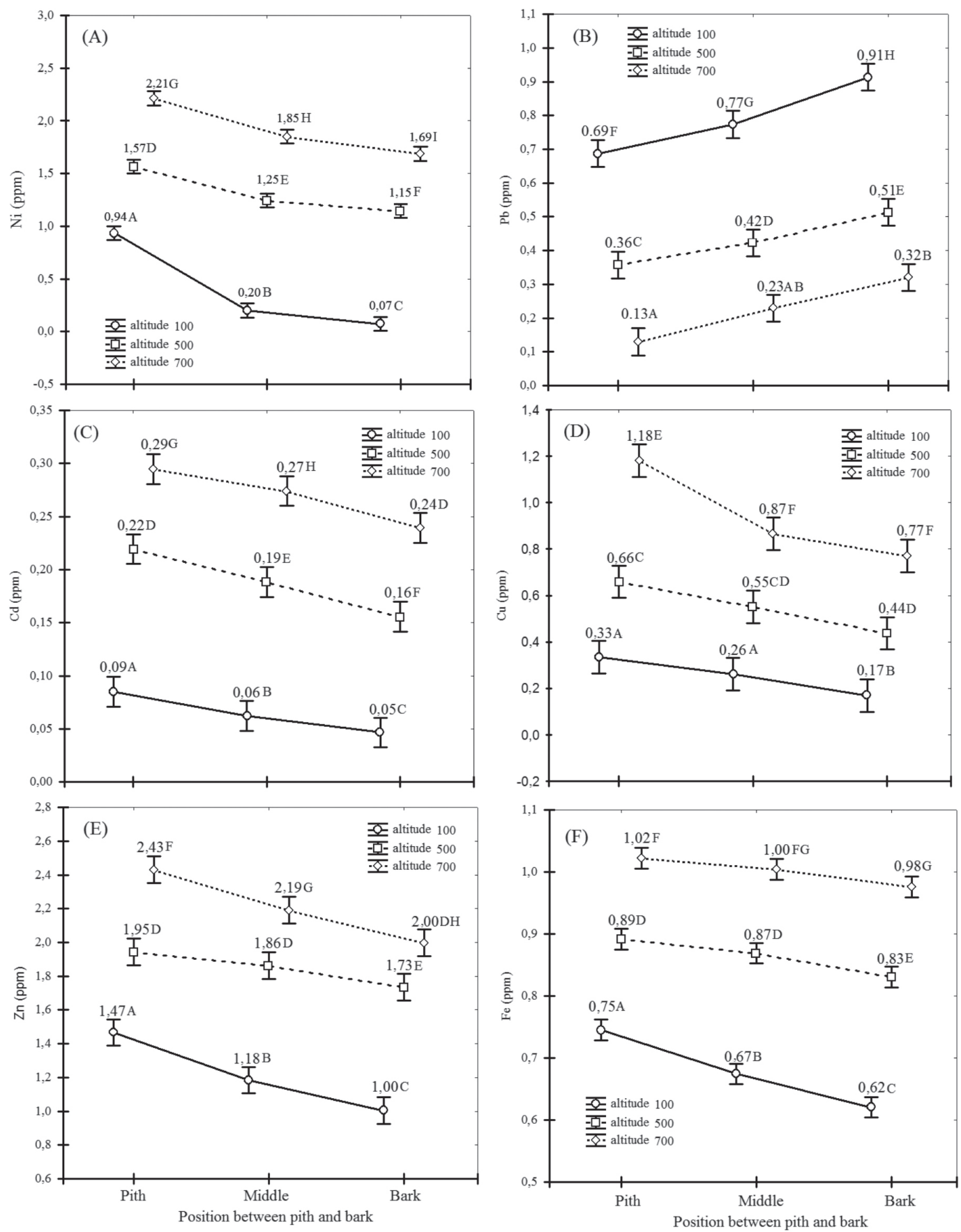

Figure 3. Nickel (a), plumb (b), cadmium (c), copper (d), zinc (e) and iron (f) content in ash variation in relation to radial position for Persian ironwood (Parrotia persica) growing in three different altitude of Iran. 


\section{Relation between mineral content with chemical properties and wood density}

Relationship between mineral content with chemical properties and wood density are shown in Table 6 . $\mathrm{Ni}, \mathrm{Cd}, \mathrm{Zn}, \mathrm{Cu}$ and $\mathrm{Fe}$ content were had positive relationships with wood density, lignin, extractives, and ash content. All of mentioned relationships were significant, except for relationship between $\mathrm{Cu}$ and wood density $(\mathrm{r}=0,46) . \mathrm{Pb}$ content presented negative significantly relationship with wood density $(\mathrm{r}=-0,57)$; lignin $(r=-0,88)$; extractives $(r=-0,91)$; and ash content $(r=-0,92)$. The all of mineral content, except for $\mathrm{Pb}$ content $(\mathrm{r}=0,82)$; presented negative correlations with cellulose content. Correlation coefficients between mineral content and oven-dried density are below $60 \%$, while these relationships between mineral content and chemical properties were above $80 \%$. Therefore, it can show that mineral content had stronger relationship with chemical properties than wood density. The highest of correction coefficients was found in $\mathrm{Zn}$-ash relationship $(\mathrm{r}=0,94)$ for Persian ironwood (Parrotia persica) in Iranian forest (Table 6).

Table 6. Values of coefficient of correlation ( $\mathrm{r}$ ) between mineral component in ash and wood properties of Persian ironwood (Parrotia persica) trees growing in Iran.

\begin{tabular}{|llllll|}
\hline Mineral & Density & oven- & & \multicolumn{5}{l|}{ Chemical compositions } \\
\cline { 3 - 6 } content in ash & dried & Cellulose & Lignin & Extractives & Ash \\
\hline $\mathrm{Ni}$ & $0,59^{*}$ & $-0,81^{* *}$ & $0,86^{* *}$ & $0,89^{* *}$ & $0,91^{* *}$ \\
$\mathrm{~Pb}$ & $-0,57^{*}$ & $0,82^{* *}$ & $-0,88^{* *}$ & $-0,91^{* *}$ & $-0,92^{* *}$ \\
$\mathrm{Cd}$ & $0,50^{*}$ & $-0,84^{* *}$ & $0,89^{* *}$ & $0,92^{* *}$ & $0,92^{* *}$ \\
$\mathrm{Cu}$ & $0,46^{\mathrm{NS}}$ & $-0,85^{* *}$ & $0,88^{* *}$ & $0,88^{* *}$ & $0,85^{* *}$ \\
$\mathrm{Zn}$ & $0,60^{*}$ & $-0,84^{* *}$ & $0,86^{* *}$ & $0,90^{* *}$ & $0,94^{* *}$ \\
$\mathrm{Fe}$ & $0,50^{*}$ & $-0,81^{* *}$ & $0,90^{* *}$ & $0,90^{* *}$ & $0,91^{* *}$ \\
\hline \multicolumn{5}{l}{} \\
\hline
\end{tabular}

Mineral content were influences by three chemical properties, except for iron content (Fe), which was correlated with two variables (Table 7). Multiple stepwise correlation analysis (Table 7) showed mineral content can be explained by model $Y=a+b * \beta_{1}+c^{*} \beta_{2}+d^{*} \beta_{3}$ (where $a, b, c$ and $d$ are model coefficient and $\beta_{\mathrm{i}}$ are wood properties) and this model presented high correlation coefficient ( $\mathrm{R}>0,93$; Table 7$)$. However, $\mathrm{Fe}$ content was explained only for two properties (ash and lignin content) and it was modeled by $Y=a+b^{*} \beta$, $+c^{*} \beta_{2}$. The ash content in the wood explained up to $82 \%$ of the Ni, complemented by the lignin content representing $7 \%$ of total variation, while variations in $\mathrm{Cd}$ were explained by extractive content $(84 \%)$ and lignin content (7\%). Pb content was correlated with ash content (84\%), lignin (8\%) and wood density (3\%). This trend was found in $\mathrm{Cu}$ and $\mathrm{Zn}$ which were related with ash (78 vs 88\%), lignin (6 vs 5\%) and wood density $(3 \%)$ of total variation. Ash, lignin and wood density had important effects in the mineral content variation for Persian ironwood. 
Table 7. Results from multiple stepwise regression analysis for the relationship between mineral content and wood properties for Persian ironwood (Parrotia persica) growing in three different altitude of Iran

\begin{tabular}{|c|c|c|c|c|c|}
\hline \multirow{2}{*}{$\begin{array}{l}\text { Mineral } \\
\text { content }\end{array}$} & \multicolumn{5}{|c|}{ Correlation parameters } \\
\hline & & $\beta_{1}$ & $\beta_{2}$ & $\beta_{3}$ & Equation \\
\hline $\mathrm{Ni}$ & Variable & $\operatorname{Ash}^{* *}$ & Lignin** & Density** & \multirow{3}{*}{$Y=-11,13+0,48^{*} \beta_{1}+0,37^{*} \beta_{2}+3,04 * \beta_{3}$} \\
\hline \multirow[t]{2}{*}{$\mathrm{R}=0,96$} & $\mathrm{R}^{2}$ ap. & 0,82 & 0,07 & 0,04 & \\
\hline & $\mathrm{R}^{2} \mathrm{mul}$. & 0,82 & 0,89 & 0,93 & \\
\hline $\mathrm{Pb}$ & Variable & Ash** & Lignin** & Density** & \multirow{3}{*}{$Y=4,90-0,14 * \beta_{1}-0,19 * \beta_{2}-0,92 * \beta_{3}$} \\
\hline \multirow[t]{2}{*}{$\mathrm{R}=0,97$} & $\mathrm{R}^{2}$ ap. & 0,84 & 0,08 & 0,03 & \\
\hline & $\mathrm{R}^{2} \mathrm{mul}$. & 0,84 & 0,92 & 0,95 & \\
\hline $\mathrm{Cd}$ & Variable & Extractives** & $\operatorname{Ash}^{* *}$ & Lignin** & \multirow{3}{*}{$\mathrm{Y}=-0,79+0,03 * \beta_{1}+0,08 * \beta_{2}+0,03 * \beta_{3}$} \\
\hline \multirow[t]{2}{*}{$\mathrm{R}=0,97$} & $\mathrm{R}^{2}$ ap. & 0,84 & 0,07 & 0,03 & \\
\hline & $\mathrm{R}^{2} \mathrm{mul}$ & 0,84 & 0,91 & 0,94 & \\
\hline $\mathrm{Cu}$ & Variable & Ash** & Lignin** & Density** & \multirow{3}{*}{$\mathrm{Y}=-5,17+0,20 * \beta_{1}+0,19 * \beta_{2}+0,67 * \beta_{3}$} \\
\hline \multirow[t]{2}{*}{$\mathrm{R}=0,93$} & $\mathrm{R}^{2}$ ap. & 0,78 & 0,06 & 0,03 & \\
\hline & $\mathrm{R}^{2} \mathrm{mul}$. & 0,78 & 0,84 & 0,87 & \\
\hline $\mathrm{Zn}$ & Variable & $\operatorname{Ash}^{* *}$ & Lignin** & Density** & \multirow{3}{*}{$\mathrm{Y}=-5,24+0,41 * \beta_{1}+0,20 * \beta_{2}+1,68 * \beta_{3}$} \\
\hline \multirow[t]{2}{*}{$\mathrm{R}=0,98$} & $\mathrm{R}^{2}$ ap. & 0,88 & 0,05 & 0,03 & \\
\hline & $\mathrm{R}^{2} \mathrm{mul}$ & 0,88 & 0,93 & 0,96 & \\
\hline $\mathrm{Fe}$ & Variable & $\mathrm{Ash}^{* *}$ & Lignin** & - & \multirow{3}{*}{$\mathrm{Y}=-1,08+0,07 * \beta_{1}+0,14 * \beta_{2}$} \\
\hline \multirow[t]{2}{*}{$\mathrm{R}=0,96$} & $\mathrm{R}^{2}$ ap. & 0,84 & 0,09 & - & \\
\hline & $\mathrm{R}^{2}$ mul. & 0,84 & 0,93 & - & \\
\hline
\end{tabular}

** Statistically significant at $99 \%$ confidence; $\mathrm{R}^{2}$ ap: Contribution of the parameter to the coefficient of determination; $\mathrm{R}^{2}$ mul: Multiple coefficient of determination.

In order to visualize the behavior of the two main variables on the mineral content is presented the figure 4. The $\mathrm{Ni}$ content increases with increment of ash and lignin content and the highest $\mathrm{Ni}, \mathrm{Pb}$ and $\mathrm{Fe}$ content is obtained when ash content is higher than $2,4 \%$ and lignin content is higher than $26,0 \%$ (Figure $4 \mathrm{~A}, 4 \mathrm{~B}$ and 4F).The $\mathrm{Cd}$ content increases with increment of ash and extractives content and the highest $\mathrm{Cd}$ content is obtained when ash content is higher than $2 \%$ and extractives content is higher than $4,5 \%$ (Figure $4 \mathrm{C}$ ). The $\mathrm{Cu}$ content increases with decreasing of ash and the increment of extractives content and the highest $\mathrm{Cu}$ content is obtained when ash content is lower than $1 \%$ and extractives content is higher than $4,5 \%$ (Figure 4D).The $\mathrm{Zn}$ content increases with increment of ash and lignin content and the highest $\mathrm{Zn}$ content is obtained when ash content is higher than 1,6\% and lignin content is higher than $26 \%$ (Figure $4 \mathrm{E}$ ). 

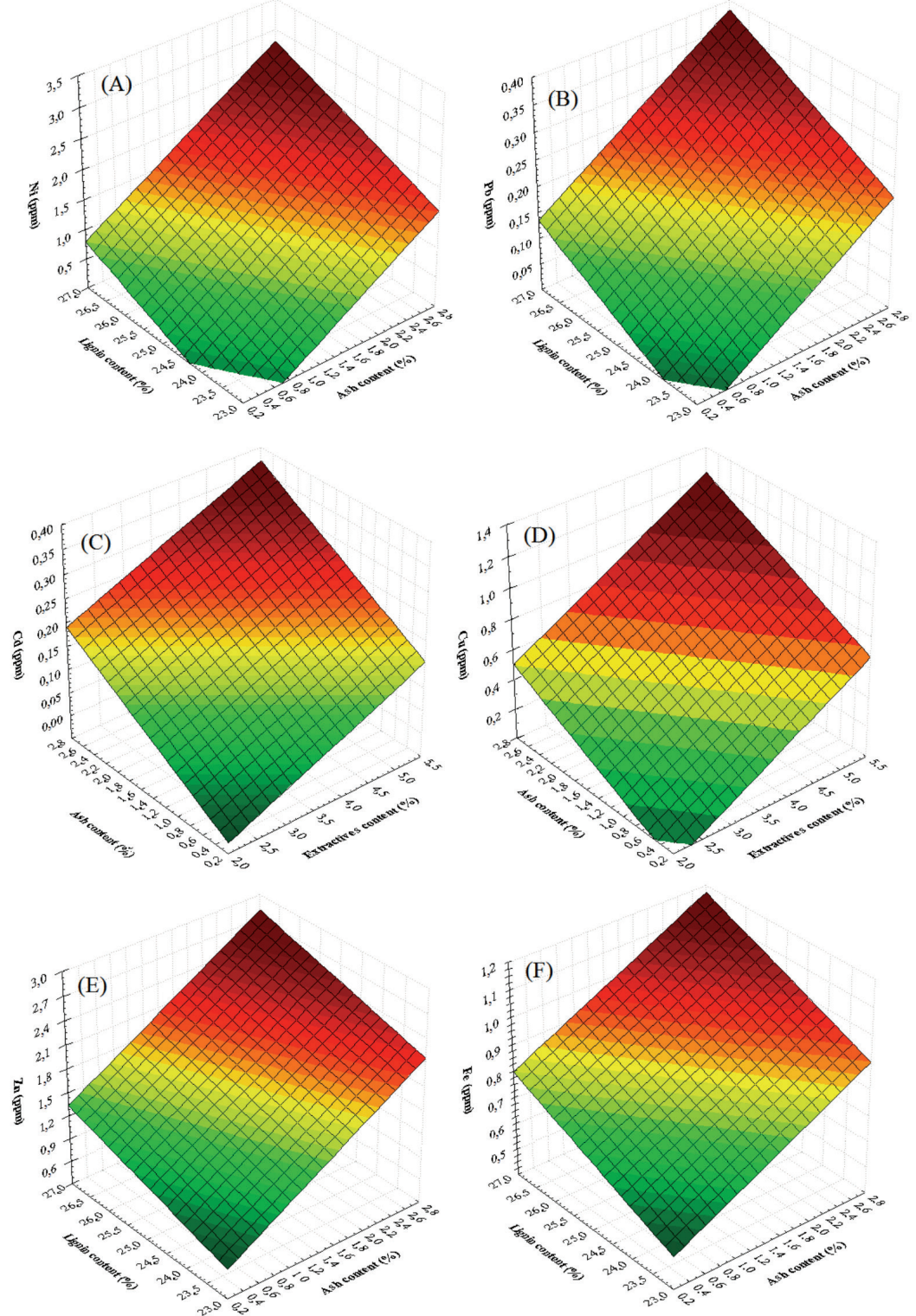

Figure 4. Response surfaces for the most significant variable correlations between mineral content and wood characteristics of Persian ironwood (Parrotia persica) growing in three different altitude of Iran.

Nickel (A), plumb (B), cadmium (C), copper (D), zinc (E) and iron (F) content. 


\section{DISCUSSION}

In general, in small amounts as micronutrients, some minerals such as zinc, nickel and copper are essential for the growth of trees and are absorbed from the soil by the roots (Marry et al. 1986). Meanwhile, some of these minerals such as $\mathrm{Pb}$ do not have any specific role in the physiological reactions of the plants and due to their chemical similarity with essential elements of their absorption by plants is possible (Kord et al. 2010). By increasing the altitude from the sea level, the cadmium (Cd), copper $(\mathrm{Cu})$, iron (Fe), nickel (Ni), and zinc $(\mathrm{Zn})$ amount in ironwood ash increased. Also, this mineral content decreased along radial axes from the pith to the bark (Figure 1 and 2). These performances of the mineral within tree (Table 2) and with sea level (Table 4) could be attributed to highest share of wood ash content in the core at a height of 700 meters above sea level. Similar trend was found in $\mathrm{Cd}$ and $\mathrm{Zn}$ concentration along radial position from the pith to the bark before and after growing season for beech wood in the two sites (Schwaney and Glindfeld sites) in Germany (Hagemeyer and Schäfer 1995).

The reverse performance in plumb content $(\mathrm{Pb})$ changes in ironwood compared with other minerals has been observed (Figure 1 and 2). As a result, the $\mathrm{Pb}$ content in ironwood decreased by increasing the altitude and increased along radial axes from the pith to the bark. Pb high content in the lower altitude (100 meters above sea level) can be ascribed to the proximity of the selected samples to the urban areas and also the pollution and environmental conditions of the region and also the higher concentration of $\mathrm{Pb}$ in the soil (Kord et al. 2010). The minimum and maximum of $\mathrm{Pb}$ content of Ironwood in three altitudes and three samples of radial position varied 0,23 to $0,79 \mathrm{Ppm}$ (Table 2 and 4), which is lower than the pb content in beech wood (0,32- 3,67 Ppm at Schwaney site and 0,30-1,51 Ppm at Glindfeld site) for different growth season (April, June, September and October) in Germany (Hagemeyer and Schäfer 1995), and lower than the pb of aspen wood (1,4 Ppm) in USA (Ragland et al. 1991). Other mineral content of aspen wood is higher than the studied species (Ragland et al. 1991).

Taneda et al. (1986), categorized nutrient concentration profiles as follows: i) a gradual decrease from pith to cambium, ii) a minimum at the heartwood/sapwood boundary region, iii) a maximum at the boundary region. $\mathrm{Ni}, \mathrm{Cd}, \mathrm{Cu}, \mathrm{Zn}$, and $\mathrm{Fe}$ in ironwood are representative of the first pattern. No element could be ascribed to the second and third category. $\mathrm{Pb}$ content wasn't in any of the above classification. Our results was agreed with beech wood and disagreed with oakwood species (Penninckx et al. 2001). They reported that the Ca, Mn and $\mathrm{K}$ in beech wood was in first pattern, while the $\mathrm{Ca}, \mathrm{Mg}, \mathrm{K}$ and $\mathrm{Mn}$ concentration was in second category for oakwood in Belgian forest.

With the increase of elevation from sea level, the lignin, ash and extractives increased but cellulose amount slightly decreased (Table 2), the reason of which can be attributed to the site conditions such as altitude, soil, climate condition, and the humidity of the region. Some researchers reported that the site variation had significantly differences on the wood different properties (Doğu, 2002, Kiaei et al. 2012). The increase of cellulose at low altitude (100 meter) (Table 4) can be associated to the more cellular wall thickness (Vaziri et al. 2009). The increase of lignin percentage on intermediate altitude (500 meters) and high elevation (700 meters) can be ascribed to the excessive cell growth and cell proliferation which increase lignin macromolecules with shorter chains naturally increasing the lignin weight amount (Vaziri et al. 2009). The same phenomenon is true in the case of extractives increment. Regarding the high percentage of extractives in Ironwood trees at a height of 700 meters above sea level (Table 4), it is very significant to produce side products such as paper pulp, tall oil and turpentine. 
Many researchers believe that there is an increase in cellulose content (due to the maturity of the cambium cells) and a decrease in the amount of extractives (due to formation of heartwood and more storage of extractives content in pith area) and lignin reduction in trees radial axis from the pith to the bark (due to the juvenile wood in the pith part) (Panshin and De Zeeuw 1980, Gominho and Figueira 1999, Scholz et al. 2007) which is similar to the chemical properties and changes achieved in this research. But no significant difference is existed among the radial position in terms of chemical properties (cellulose, lignin, extractives and ash) in the ironwood samples.

Some researchers have reported that wood density decreases with age or distance from the pith (Pinto et al. 2004). This is supported by the fact that heartwood is usually known to be of a lower density than sapwood. Our results showed that there is a decreasing trend of wood density variations along the radial axis from the pith to the bark and an increasing pattern at intermediate altitude. The increase of wood density around the pith part of tress and intermediate altitude was due to the existence of more ratio of heartwood-sapwood and saving of more extractives composition in these parts.

Ash content had most important role on the variation of $\mathrm{Ni}(82 \%), \mathrm{Pb}(84 \%), \mathrm{Cu}(78 \%), \mathrm{Zn}(88 \%)$ and $\mathrm{Fe}(84 \%)$ compared to other wood chemical properties (Table 7 and Figure 4). Mineral content are distributed along and radial direction in the trees (Sander and and Ericsson 1998) and they are located in the ash after combustion process (Vassilev et al. 2013). Then they are widely correlated with ash content as it was showed in ironwood from Iran (Table 7). However Cd content was related firstly with extractive (84\%) and afterwards with ash content (7\%). Another important observation showed that the lignin content was the second chemical variables related with mineral content (Table 7): in Ni with $7 \%$ of variation, in $\mathrm{Pb}$ with $8 \%$, in $\mathrm{Cu}$ with 6\%, in $\mathrm{Zn}$ with 5\% and in Fe with 9\% (Table 7 and Figure 4).

\section{CONCLUSIONS}

In this research, the effects of altitude and radial direction on the mineral content, wood density and chemical properties and the relationship between mineral content and wood density of ironwood were studied in Noshahr region in Iranian forest. The following conclusions were obtained from this research:

Analysis of variance (ANOVA) indicated that the effect of altitude on the chemical properties, wood density and mineral content were significant. With increasing of altitude from 100 to $700 \mathrm{~m}$, the values of lignin, extractives, ash, and mineral content (except $\mathrm{Pb}$ content) increased, while $\mathrm{Pb}$ and cellulose content decreased (slightly). Maximum and minimum of wood density were found at intermediate and low altitudes.

ANOVA indicated that there are significant differences between radial axes with wood density and mineral content, while had not on the chemical characteristics. The wood density and mineral content (except $\mathrm{Pb}$ content) decreased along radial position with increasing distance from the pith.

Interaction effects between altitude and radial position on the wood density and mineral content were significant. This factor had not significant differences on the chemical properties. In each of fixed altitude, the mineral content except $\mathrm{Pb}$ content and wood density was decrease along radial position from the pith to the bark.

Results of Pearson correlation showed that there are significant differences between mineral content with wood density and chemical properties except the relationship between $\mathrm{Cu}$ and wood density. Positive relationships were found between mineral content (except $\mathrm{Pb}$ ) content with chemical properties (except cellulose content) and wood density. 
The ash content of ironwood had important significant roles on the wood mineral content except the $\mathrm{Cd}$ content. This property explained up of $82 \%$ of the $\mathrm{Ni}, 84 \%$ of the $\mathrm{Pb}, 78 \%$ of the $\mathrm{Cu}, 88 \%$ of the $\mathrm{Zn}$ and $84 \%$ of the Fe. The second and third of variables are lignin content and density, which had important effects on mineral content.

Variations in Cd content were explained by extractives content $(84 \%)$ and by ash content $(7 \%)$ and by lignin content $(3 \%)$ in ironwood.

\section{REFERENCES}

Aerts, R.; Chapin, F.S. III. 2000. The mineral nutrition of wild plants revisited: a re-evaluation of processes and patterns. Advance in Ecological Research 30:1-67.

Attiwill, P.M. 1980. Nutrient cycling in a Eucalyptus oblique (L'Hérit.) forest.IV. Nutrient uptake and nutrient return. Australian Journal of Botany 28: 199-222.

Augusto, L.; Ranger, J.; Ponette, Q.; Rapp, M. 2000. Relationships between forest tree species, stand production and stand nutrient amount. Annals of Forest Science 57: 313-324.

Creber, G.T.; Chaloner, W.G. 1984. Influence of environmental factors on the wood structure of living and fossil trees. Botanical Review 50(4): 357-448.

Doğu, D.A. 2002. The factors affecting wood structure. Journal of Eastern Mediterranean Forestry Research Institute 8:81-102.

Eckstein, R.; Karlsson, P.S.; Weih, M. 1999. Leaf life span and nutrient resorptionas determinants of plant nutrient conservation in temperate-arctic regions. New Phytologist 143: 177-190.

Gominho, J.; Figueira, J. 1999. Within-tree variation of heartwood, extractiveand wood density in the Populus deltoids hybrid. Wood and Fiber Science 33(1):3-8.

Hagemeyer, J.; Schäfer, H. 1995. Seasonal variations in concentrations and radial distribution patterns of $\mathrm{Cd}, \mathrm{Pb}$ and $\mathrm{Zn}$ in stem wood of beech trees (Fagus sylvatica L.). Science of the Total Environment 166 (1): 77-87.

Hillis, W.E. 1987. Heartwood and tree exudates, Springer-Verlag, Berlin.

Hylen, G. 1997. Genetic variation of wood density and its relationship with growth traits in young Norway spruce. Silvae Genetica 46: 55-60.

Kiaei, M.; Nouri-Sadegh, A.; Moya, R. 2013. Site variation of tracheid features and static bending properties in Pinus eldarica wood. Cellulose Chemistry and Technology 47 (1-2): 49-59.

Kord, B.; Mataji, A.; Babaie-Kafaki, S.; Saadatmand, S. 2010. Comparison of lead content absorption in different parts of Eldar pine (Pinus eldarica Medw.) in Tehran city. Iranian Journal of Forest and Poplar Research 18 (2): 265-277.

Marry, R.H.; Tiller, K.G.; Alston, A.M. 1986. The effect of contamination of soil with copper, lead and arsenic on the growth and composition of plant. Journal of Plant and Soil 91: 115-128. 
Meerts, P. 2002. Mineral nutrient concentrations in sapwood and heartwood: a literature review. Annals of Forest Science 59: 713-722.

Moya, R.; Perez, D. 2008. Effect of physical and chemical soil properties on physical wood characteristics of Tectona grandis plantations in Costa Rica. Journal of Tropical Forest Science 20(4): 248-257.

Moya, R.; Calvo-Alvardo J. 2012. Variation of wood color parameters of Tectona grandis and its relationship with physical environmental factors. Annals of Forest Science 69 (8): 947-959.

Myre, R.; Camiré, C. 1994. Distribution de $\mathrm{P}, \mathrm{K}, \mathrm{Ca}, \mathrm{Mn}$ et $\mathrm{Mg}$ dans la tigedes mélèzeseuropéen et laricin. Annual of Forest Science 51: 121-134.

Nambiar, E.K.S.; Fife D.N. 1991. Nutrient retranslocation in temperate conifers. Tree Physiology 9: 185-207.

Panshin, A.J., De Zeeuw, C. 1980. Textbook of wood technology. McGraw-Hill, USA.

Parsakhoo, A.; Jalilvand, H. 2009. Effects of Iron Wood (Parrotia persica C.A. Meyer) Leaf Litter on Forest Soil Nutrients Content. American-Eurasian Journal of Agriculture \& Environmental Science 5 (2): 244-249.

Penninckx, V.; Glineur, S.; Gruber, W.; Herbauts, J.; Meerts, P. 2001. Radial variations in wood mineral element concentrations: a comparison of beech and pedunculate oak from the Belgian Ardennes. Annals of Forest Science 58(3):253-260.

Pinto, I.; Pereira, H.; Usenius, A. 2004. Heartwood and sapwood development within maritime pine (Pinus pinaster Ait.) stems. Trees 18: 284-294.

Pitman, R.M. 2006. Wood ash use in forestry - a review of the environmental impacts. Forestry 79(5): 563-588.

Ragland, K.W.; Aerts, D.J.; Baker, A.J. 1991. Properties of wood for combustion analysis. Bioresource Technology 37:161-168.

Roo-Zielinska, E.; Solon, J. 1997. Effect of geographical location on species composition, vegetation structure, diversity and phytoindicative characteristics in pine forests. Environmental Pollution 98(3) 347-360.

Rowell, R.M. Young, R.A.; Rowell, J.K. 1997. Paper and composites from Agro-based Resources, CRC Lewis Publishers, Boca Raton, FL, USA.

Sander, M.L.; Ericsson, T. 1998. Vertical distributions of plant nutrients and heavy metals in Salix viminalis stems and their implications for sampling. Biomass and Bioenergy 14 (1): 57-66.

Silva, J.C.; Borralho, N.M.G.; Araújo, J.A.; Vaillancourt, R.E.; Potts, B.M. 2009. Genetic parameters for growth, wood density and pulp yield in Eucalyptus globulus. Tree Genetics and Genomes 5: 291-305.

Scholz, G.; Liebner, F.; Koch, G.; Bues, C.T.; Günther, B.; Bäucker, E. 2007. Chemical, anatomical and technological properties of Snakewood [Brosimum guianense (Aubl.) Huber]. Wood Science and Technology 41 (8): 673-686.

Taneda, K.; Ota, M.; Nagashima, M. 1986. The radial distribution and concentration of several chemical elements in woodsof five japanese species. Mokuzai Gakkaishi 32 (10): 833-841. 
Trugilho, P.; Lima, J.; Mendes, L. 1996. Influência da idade nas características físico-químicas e anatómicas da madeira de Eucalyptussaligna. Cerne 2(1): 94-111.

Tessier, L.; Nola, P.; Serre-Bachet, F. 1994. Deciduous quercus in the Mediterranean region: Tree ringclimate relationships. New Phytologist 126(2): 355-367.

Vassilev V. S.; Baxter, D.; Vassileva, C.G. 2013. An overview of the behavior of biomass during combustion: Part I. Phase-mineral transformations of organic and inorganic matter. Fuel 112: 391-449.

Vaziri, V.; Hosseini, S.Z.; Dehghani, M.R. 2009. Effect of Altitude on Fiber Characteristics, Chemical Composition and Kraft Yield Pulp of Brutian Pine (Pinus brutia). Journal of Wood and Forest Science and Technology 16(1): 1-14.

Wimmer, R.; Downes, G.M.; Evans, R.; Rasmussen, G.; French, J. 2002. Direct effects of wood characteristics on pulp and handsheet properties of Eucalyptus globulus. Holzforschung 56: 244-252.

Wimmer, R.; Downes, G.M.; Evans, R.; French, J. 2008. Effects of site on fibre kraft pulp and handsheet properties of Eucalyptus globulus. Annals of Forest Science 65: 602.

Wodzicki, T.J. 2001. Natural factors affecting wood structure. Wood Science and Technology 35: 5-26.

Woodwell, G.L.; Whittaker, R. H.; Houghton, R. A. 1975. Nutrient concentrations in plants in the Brookhaven oak-pine forest. Ecology 56: 318-332.

Wilson, K.; White, D. J. B. 1986. The anatomy of wood: Its diversity and variability. Stobart and Son LTD., London.

Werkelin, J.; Skrifvars, B.J.; Hupa, M. 2005. Ash-forming elements in four Scandinavian wood species. Part 1: summer harvest. Biomass and Bioenergy 29: 451-466.

Yilmaz, M.; Serdar, B.; Altun, L.; Usta, A. 2008. Relationships between environmental variables and wood anatomy of Quercus pontica C. KOCH (Fagaceae). Fresenius Environmental Bulletin 17 (7b): 902-910.

Zhang, S.Y.; Morgenstern, E.K. 1995. Genetic variation and inheritance of wood density in black spruce (Picea mariana) and its relationship with growth: Implications for tree breeding. Wood Science and Technology 30: 63-75.

Zhang, S.Y. 1998. Effect of age on the variation, correlations and inheritance of selected wood characteristics in black spruce (Picea mariana). Wood Science and Technology 32: 197-204.

Zobel, B.; Van Buijtenen, B.J. 1989. Wood variation: Its causes and control. SpringerVerlag, New York. 363p. 